\title{
Organic products selectivity for Trichogramma pretiosum (Hymenoptera: Trichogrammatidae)
}

\author{
Seletividade de produtos orgânicos para Trichogramma pretiosum \\ (Hymenoptera: Trichogrammatidae)
}

\author{
Débora Mello da Silva', Adeney de Freitas Bueno ${ }^{2 *}$
}

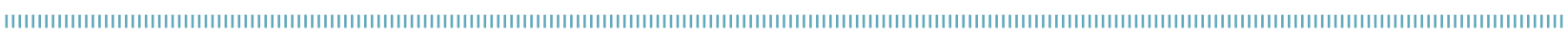

\begin{abstract}
The selectivity of different insecticides, fungicides and fertilizers used in organic soybean cropping was evaluated according to the protocols proposed by the Pesticides and Beneficial Organisms Working Group of the International Organization for Biological Control (IOBC) concerning adults and pupae of the egg parasitoid Trichogramma pretiosum Riley (Hymenoptera: Trichogrammatidae) under laboratory conditions. Treatments 1) baculovirus anticarsia $140 \times 10^{9} \mathrm{cpi}$; 2) Bacillus thuringiensis $16.8 \mathrm{~g}$; 3) azadirachtin-A, azadirachtin-B, nimbina and salamina $9.6 \mathrm{ppm}$; 4) rotenoids $4 \% 4 \mathrm{~L} ; 5$ ) nitrogen $1.3 \%$, phosphorus $3.0 \%$ and total organic carbon $8.0 \% 3 \mathrm{~L}$; 6) sodium silicate $2 \% 4 \mathrm{~L}$; 7) copper $7 \%$ + calcium 3.3\% $1.8 \mathrm{~L}$; 8) sulfur $20 \%$ + quicklime $10 \% 1.8 \mathrm{~L}$ were in general safe (class 1) to both adults and pupae of T. pretiosum. Differently, chlorpyrifos (control treatment) was harmful to this parasitoid. Therefore, the utilization of the tested natural derived products in the production of organic soybean is viable, without impairing the natural biological control allowed by T. pretiosum. Furthermore, both management techniques can indeed be used together in organic cropping aiming at reaching increasing or complementary control of target pests. Chlorpyrifos use, on the other hand, whenever possible, should be replaced by other products more compatible with biological control preservation.
\end{abstract}

KEYWORDS: biological control; selective products, organic cropping.
RESUMO: A seletividade de diferentes inseticidas, fungicidas e fertilizantes usados no cultivo de soja orgânica foi avaliada de acordo com os protocolos propostos pela Pesticide and Beneficial Organisms Working Group of the International Organization for Biological Control (IOBC) sobre pupas e adultos de Trichogramma pretiosum Riley (Hymenoptera: Trichogrammatidae) em condiçóes de laboratório. Os tratamentos 1) baculovírus anticarsia $140 \times 10^{9} \mathrm{cpi}$; 2) Bacillus thuringiensis $16,8 \mathrm{~g}$; 3) azadirachtin-A, azadirachtin-B, nimbina e salamina 9,6 ppm; 4) rotenoides $4 \% 4 \mathrm{~L}$; 5) nitrogênio 1,3\%, fósforo $3,0 \%$ e carbono orgânico total 8,0\% 3 L; 6) silicato de sódio $2 \%$ 4 L; 7 ) cobre $7 \%$ + cálcio 3,3\% 1,8 L; 8) enxofre $20 \%$ + cal virgem $10 \% 1,8 \mathrm{~L}$ foram, no geral, inócuos (classe 1) para pupas e adultos de T. pretiosum. Diferentemente, clorpirifós (tratamento controle) foi nocivo para esse parasitoide. A utilização dos produtos de origem natural avaliados é viável na sojicultura orgânica sem impactar o controle biológico promovido por T. pretiosum. Ambas as táticas de manejo podem ser utilizadas conjuntamente na agricultura orgânica objetivando aumentar ou complementar o controle da praga-alvo. O uso do clorpirifós, por outro lado, sempre que possível, deve ser substituído por outros produtos mais compatíveis com a preservação do controle biológico.

PALAVRAS-CHAVE: controle biológico; produtos seletivos; cultivo orgânico. 


\section{INTRODUCTION}

Soybean is an important crop for many countries, and, from Argentina to the Southeastern United States, some caterpillars have adversely affected yields (PANIZZI; CoRrêA-Ferreira, 1997; Hoffmann-Campo et al., 2003). To address this problem, chemical insecticides are the main pest-control method presently used by farmers worldwide (SonG; Swinton, 2009). Nevertheless, the continuous and sometimes excessive use of these pesticides has raised great concern, because of the contamination not only of food chains but also of potable water (Lairon, 2010). In order to mitigate these problems, in recent decades, the production and consumption of organic food has increased (Willer; Kilcher, 2009). Among all the organic crops, soybeans are one of the most important, being used for both human consumption and organic livestock production (KLedal et al., 2007). Soybeans alone supply half of the global demand for vegetable oil and protein (Oerke; Dehne, 2004), and their organic production has been extremely profitable, since prices of organic soybeans have historically been highly lucrative compared to other major field crops (McBRIDE; GREenE, 2009). However, this profit could be further increased if problems with pests were reduced (OERKE, 2006).

An important practice for addressing pest problem is the use of biological control methods, which has been emphasized by researchers as a promising alternative to insecticide application. It is economically and ecologically feasible for soybean farmers (BuENo et al., 2009), in addition to helping to reduce negative impacts of intensive agriculture on the environment (VAn Lenteren; Bueno, 2003). Of the available biological-control tools that can be used in organic cropping, egg parasitoids have been recognized as important agents, since they occur worldwide and parasitize eggs of a wide diversity of pests (Bueno et al., 2009). Among parasitoids, the genus Trichogramma is considered to have a high potential in controlling the soybean caterpillar complex (BuENo et al., 2012).

Despite the importance of egg parasitoids for insect control, the use of approved products of biological and mineral origin, or other alternative products authorized for use in organic farming, is still necessary in organic cropping (Zehnder et al., 2007). Therefore, selective organic products are of great value. A significant advantage of selective products is their effectiveness against the pest, with minimal side-effects on beneficial arthropods (Bueno; Freitas, 2004; Bacci et al., 2007). Even though of great importance, there is a lack of studies on the selectivity of organic products on T. pretiosum. Importantly, organic agriculture is not a panacea or a prerequisite for achieving feasible and ecologically-based pest management (Zehnder et al., 2007); understanding the effects of alternative products - that are commonly used in organic soybean crops - on the population densities of T. pretiosum is extremely important and was the main goal of this study.

\section{MATERIAL AND METHODS}

Trials were carried out in a fully randomized experimental design with 10 treatments (Table 1 ) and 5 replications under controlled environmental conditions $-25 \pm 1^{\circ} \mathrm{C} ; 70 \pm 10 \%$ relative humidity; and 14/10 h (L/D) photoperiod. All the methodology followed the standardized protocols proposed by the International Organization of Biological Control (IOBC/ WPRS) (HASSAN, 1992), summarized as follows.

\section{Adult trial}

Anagasta kuehniella (Zeller) (Lepidoptera: Pyralidae) eggs (250 eggs) parasitized by Trichogramma pretiosum Riley (Hymenoptera: Trichogrammatidae) were placed in small vials ("emergence tubes", $12 \mathrm{~cm}$ long and $22 \mathrm{~mm}$ in diameter), each containing a droplet of honey on its inner wall. The glass vials were then sealed with plastic film and maintained under controlled environmental conditions $\left[25 \pm 1^{\circ} \mathrm{C} ; 70 \pm 10 \% \mathrm{RH}\right.$; and $14 / 10 \mathrm{~h}(\mathrm{~L} / \mathrm{D})$ photoperiod], until the parasitoids emerged. After parasitoid emergence, glass plates $(13 \times 13 \mathrm{~cm})$ were sprayed with treatments described in Table 1, or with distilled water (control), ensuring a deposit of $1.25 \pm 0.25 \mathrm{mg} / \mathrm{cm}^{2}$ accordingly to the IOBC/WRPS standardized protocols (Hassan, 1992). When dry ( 2 to $3 \mathrm{~h}$ later), the plates were placed in aluminumframe cages, using the cage arrangement proposed by the IOBC (HASSAN, 1992). The vials containing the parasitoids were then connected to the cages, exposing the adult parasitoids to the dry residues on the glass plates. Twenty-four hours after, the parasitoids were released into the cages, numbered cards containing host egg masses (250 A. kuehniella eggs) and honey droplets were inserted. A second card was placed in each cage at the second day of the experiment.

\section{Pupae trial}

Cardboard squares (around $1 \mathrm{~cm}^{2}$ ) with approximately 250 A. kuehniella eggs each were offered for $24 \mathrm{~h}$ to freshly emerged T. pretiosum females in vials. A sufficient number of females were used to guarantee close to $100 \%$ parasitism. These cards were then transferred into vials and kept for 168 to $192 \mathrm{~h}$ to obtain T. pretiosum pupae, respectively (Cônsoli et al., 1999), which were then sprayed with the treatments shown in Table 1. After being sprayed, pupae were allowed to dry for $2 \mathrm{~h}$ and then placed in the cage arrangement proposed by the IOBC (Hassan, 1992) following the same IOBC protocol previously described (Hassan, 1992).

\section{Evaluations and analyses}

Parasitism (\%) and parasitoid emergence (\%) were evaluated. We analyzed the assumption of normality (SHAPIRO; WILK, 1965) and homogeneity of variance of treatments in these parameters 
(BURR; Foster, 1972). Whenever data did not follow the normality or homogeneity of variance, a transformation was performed into arcsin $\sqrt{\mathrm{X} / 100}$ to allow for ANOVA. The means were compared by Tukey's test $(\mathrm{p} \leq 0.05)$ for statistical significance (SAS InstituTe, 2001). Furthermore, the reduction in T. pretiosum parasitism as related to the control treatment was computed by the equation: $\mathrm{E}(\%)=(1-\mathrm{Vt} / \mathrm{Vc}) \times 100$, in which $\mathrm{E}(\%)$ is the percent reduction in parasitism; $\mathrm{Vt}$ is the median parasitism for the treatment tested; and $V_{c}$ is the average parasitism observed for the control treatment (water). The treatments were classified according to the IOBC standards as follows: class 1, harmless ( $\mathrm{E}<30 \%)$; class 2, slightly harmful $(30 \% \leq \mathrm{E} \leq 79 \%)$; class 3, moderately harmful $(80 \% \leq \mathrm{E} \leq 99 \%)$; and class 4, harmful (E > 99\%) (Hassan, 1992).

\section{RESULTS}

\section{Adult trial}

One day after the contact of adult parasitoids with the products, only the harmful control (chlorpyrifos $384 \mathrm{~g}$ ) differed statistically from the remaining treatments with respect to parasitism $(\mathrm{p}<0.0001$, $\mathrm{F}=59.1, \mathrm{df}_{\text {model }}=9, \mathrm{df}_{\text {residue }}=40$ ) (Table 2), thus allowing the remaining treatments (organic treatments) to be classified as harmless (class 1) (Table 3). Similarly, two days after the contact of adult parasitoids with the products, parasitism recorded at treatments
1. baculovirus anticarsia $140 \times 10^{9} \mathrm{cpi}$;

2. Bacillus thuringiensis $16.8 \mathrm{~g}$;

3. Azadirachtin-A, azadirachtin-B, nimbina and salamina $9.6 \mathrm{ppm}$;

4. rotenoids $4 \mathrm{~L}$;

5. nitrogen $1.3 \%$, phosphorus $3.0 \%$ and total organic carbon $8.0 \% 3 \mathrm{~L}$;

6. sodium silicate $2 \% 4 \mathrm{~L}$; and

7. copper $7 \%+$ calcium $3.3 \% 1.8 \mathrm{~L}$ were similar to control $\left(\mathrm{H}_{2} \mathrm{O}\right)$ (Table 2).

Parasitism observed at chlorpyrifos $384 \mathrm{~g}$ and sulfur $20 \%$ + quicklime 10\% $1.8 \mathrm{~L}$ differed statistically from the remaining treatments $\left(\mathrm{p}<0.0001, \mathrm{~F}=14.41, \mathrm{df}_{\text {model }}=9, \mathrm{df}_{\text {residue }}=40\right)$ (Table 2), being classified as harmful (class 4) and slightly harmful (class 2), respectively (Table 3 ).

\section{Pupae trial}

Results achieved in the test with T. pretiosum pupae were similar to those attained for the adult phase of this parasitoid (Table 2). In general, the viability of $T$. pretiosum pupae sprayed with the different products was significantly lower only in the treatment with chlorpyrifos at the dosage of $384 \mathrm{~g}$ (harmful control). For all the remaining treatments (used in the management of organic soybeans), the emergence of adults from pupae sprayed with the different natural products

Table 1. Treatments tested against pupae and adults of the egg parasitoid Trichogramma pretiosum.

\begin{tabular}{|c|c|c|c|}
\hline Product & Formulation & Provider/manufacturer & $\begin{array}{l}\text { Dosage } \\
180 \mathrm{~L} \mathrm{H}_{2} \mathrm{O}\end{array}$ \\
\hline Baculovirus $\mathrm{AEE}{ }^{\circledR}$ & Baculovirus anticarsia $7 \times 10^{9} \mathrm{cpi} / \mathrm{g}$ & $\begin{array}{c}\text { EMBRAPA Employees } \\
\text { Association AEE/CNPSoja }\end{array}$ & $140 \times 10^{9} \mathrm{cpi}$ \\
\hline 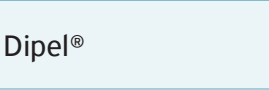 & Bacillus thuringiensis $33.6 \mathrm{~g} / \mathrm{L}$ & $\begin{array}{c}\text { Sumitomo Chemical of Brazil } \\
\text { Representatives Ltd }\end{array}$ & $0.5 \mathrm{~L}$ \\
\hline Neemseto ${ }^{\circledR}$ & $\begin{array}{c}\text { Neem oil } \\
\text { (azadirachtin-A, azadirachtin-B, } \\
\text { nimbina and salamina } 2.389 \text { ppm/L) }\end{array}$ & Cruangi Neem of Brazil Ltd & $4.0 \mathrm{~L}$ \\
\hline Arrast $^{\circledast}$ & $\begin{array}{l}\text { Deguelia utilis extract } \\
\text { (rotenoids 4\%) }\end{array}$ & $\begin{array}{l}\text { Humânita Chemical and } \\
\text { Pharmaceutical S.A. }\end{array}$ & $4.0 \mathrm{~L}$ \\
\hline Fish-Fertil Indure ${ }^{\circledR}$ & $\begin{array}{l}\text { Derivatives from crustaceans shells } \\
\text { (nitrogen } 1.30 \% \text {, phosphorus } 3.0 \% \\
\text { and total organic carbon } 8.0 \% \text { ) }\end{array}$ & $\begin{array}{c}\text { Fish Industries and } \\
\text { Commerce of Fertilizers Ltd }\end{array}$ & $3.0 \mathrm{~L}$ \\
\hline Na silicate & Sodium silicate $2 \%$ dissolved in $\mathrm{H}_{2} \mathrm{O}$ & * & $4.0 \mathrm{~L}$ \\
\hline Borda-Ferti pH7 $7^{\circledR}$ & Copper $7 \%$ + calcium 3.3\% & $\begin{array}{l}\text { Planalquímica of Brazil } \\
\text { Chemical Industry Ltd }\end{array}$ & $1.8 \mathrm{~L}$ \\
\hline Lime-sulfur mixture & $\begin{array}{l}\text { Sulfur } 20 \%+\text { quicklime } 10 \% \\
\text { (PoLITo, 2000) }\end{array}$ & * & $1.8 \mathrm{~L}$ \\
\hline $\begin{array}{l}\text { Positive control } \\
\left.\text { (Lorsban } 480 \mathrm{CE}^{\circledR}\right)\end{array}$ & Chlorpyrifos $480 \mathrm{~g} / \mathrm{L}$ & Dow AgroSciences Industrial Ltd & $0.8 \mathrm{~L}$ \\
\hline Negative control & Distilled $\mathrm{H}_{2} \mathrm{O}$ & - & - \\
\hline
\end{tabular}

*Mixture prepared at EMBRAPA Soybean to be used in the experiment. 
was similar among treatment except for NA silicate $2 \%$ that promoted lower parasitoid emergence $(78,7 \%)$ compared to the control $(89,8 \%)\left(\mathrm{p}<0.0001 ; \mathrm{F}=109.7 ; \mathrm{df}_{\text {model }}=9\right.$; $\left.\mathrm{df}_{\text {residue }}=40\right)($ Table 2$)$. Thus, all products used on organic soybeans evaluated in this experiment were classified as harmless (class 1) (Table 3) for the pupae of T. pretiosum. Chlorpyrifos, used in the test as control, was classified as moderately harmful (class 3 ) to this egg parasitoid stage (Table 3). New eggs were offered to the parasitoid adults emerged from the pupae sprayed with the different treatments until the second day after

Table 2. Side effects of organic agricultural supplies sprayed on the egg parasitoid Trichogramma pretiosum.

\begin{tabular}{|c|c|c|c|c|c|}
\hline \multirow[b]{2}{*}{$\begin{array}{l}\text { Treatment } \\
\text { (dosage/180 L H } 0 \text { ) }\end{array}$} & \multirow{2}{*}{$\begin{array}{c}\text { Sprayed pupae } \\
\text { Parasitoid } \\
\text { emergence } \\
(\%)^{\#, \&}\end{array}$} & \multicolumn{2}{|c|}{1 day after adult emergence } & \multicolumn{2}{|c|}{2 days after adult emergence } \\
\hline & & $\begin{array}{c}F_{1} \\
\text { parasitism } \\
(\%)^{\#, \&}\end{array}$ & $\begin{array}{c}F_{1} \text { parasitoid } \\
\text { emergence } \\
(\%)^{\#, \&}\end{array}$ & $\begin{array}{c}\mathbf{F}_{1} \\
\text { parasitism } \\
(\%)^{\#}\end{array}$ & $\begin{array}{c}F_{1} \text { parasitoid } \\
\text { emergence } \\
(\%)^{\#, \&}\end{array}$ \\
\hline \multicolumn{6}{|l|}{ Assay 1 = adult } \\
\hline $\begin{array}{l}\text { Baculovírus anticarsia } \\
\left(140 \times 10^{9} \mathrm{cpi}\right)\end{array}$ & * & $82.6 \pm 3.9 a b$ & $95.9 \pm 1.5^{\mathrm{ns}}$ & $76.6 \pm 6.2 \mathrm{a}$ & $91.8 \pm 2.0^{\text {ns }}$ \\
\hline Bacillus thuringiensis (16.8 g) & - & $86.6 \pm 1.8 a b$ & $93.7 \pm 3.6$ & $79.7 \pm 5.1 \mathrm{a}$ & $87.3 \pm 1.5$ \\
\hline Neem oil (9.6 ppm) & - & $89.4 \pm 3.4 a$ & $87.1 \pm 6.6$ & $58.6 \pm 11.8 a b$ & $90.2 \pm 3.2$ \\
\hline Deguelia utilis extract (4 L) & - & $86.6 \pm 4.5 a b$ & $93.0 \pm 3.3$ & $72.1 \pm 7.2 \mathrm{ab}$ & $87.2 \pm 4.8$ \\
\hline $\begin{array}{l}\text { Derivatives from } \\
\text { crustaceans }(3 \mathrm{~L})\end{array}$ & - & $83.2 \pm 3.2 \mathrm{ab}$ & $97.7 \pm 1.4$ & $81.3 \pm 3.6 a$ & $91.2 \pm 2.5$ \\
\hline Na silicate $2 \%$ (4 L) & - & $88.4 \pm 0.8 a b$ & $98.8 \pm 0.5$ & $55.2 \pm 5.4 a b$ & $84.2 \pm 4.4$ \\
\hline Copper $7 \%+$ calcium 3.3\% (1.8 L) & - & $88.2 \pm 2.6 \mathrm{ab}$ & $94.4 \pm 2.9$ & $69.9 \pm 5.1 \mathrm{ab}$ & $85.9 \pm 4.9$ \\
\hline $\begin{array}{l}\text { Sulfur } 20 \%+\text { quicklime } 10 \% \\
(1.8 \mathrm{~L})\end{array}$ & - & $72.7 \pm 5.6 b$ & $90.4 \pm 4.4$ & $42.4 \pm 10.12 b$ & $81.9 \pm 10.3$ \\
\hline Chlorpyrifos (384 g) & - & $0.0 \pm 0.0 \mathrm{c}$ & -- & $0.0 \pm 0.0 \mathrm{c}$ & - \\
\hline Control $\left(\mathrm{H}_{2} \mathrm{O}\right)$ & - & $78.5 \pm 3.9 \mathrm{ab}$ & $90.2 \pm 3.6$ & $79.1 \pm 2.9 \mathrm{a}$ & $85.4 \pm 5.3$ \\
\hline CV (\%) & - & 10.4 & 12.3 & 23.98 & 13.82 \\
\hline F value & - & 59.1 & 1.0 & 14.41 & 0.30 \\
\hline $\mathrm{p}$-value & - & $<0.0001$ & 0.4538 & $<0.0001$ & 0.9611 \\
\hline $\mathrm{df}_{\text {model }}$ & - & 9 & 8 & 9 & 8 \\
\hline $\mathrm{df}_{\text {residue }}$ & - & 40 & 36 & 40 & 36 \\
\hline \multicolumn{6}{|l|}{ Assay 2 = pupae } \\
\hline $\begin{array}{l}\text { Baculovírus anticarsia } \\
\left(140 \times 10^{9} \mathrm{cpi}\right)\end{array}$ & $95.6 \pm 0.3 a$ & $85.7 \pm 4.6 \mathrm{a}$ & $91.7 \pm 2.3 \mathrm{ab}$ & $88.3 \pm 4.2 \mathrm{a}$ & $94.2 \pm 3.7^{2 ; \mathrm{ns}}$ \\
\hline Bacillus thuringiensis ( $16.8 \mathrm{~g}$ ) & $88.9 \pm 1.8 \mathrm{abc}$ & $89.2 \pm 2.6 \mathrm{a}$ & $92.8 \pm 2.8 a b$ & $91.5 \pm 1.3 a$ & $96.7 \pm 2.0$ \\
\hline Neem oil (9.6 ppm) & $80.4 \pm 4.5 b c$ & $92.9 \pm 2.3 \mathrm{a}$ & $98.0 \pm 1.3 \mathrm{a}$ & $91.2 \pm 2.0 \mathrm{a}$ & $96.9 \pm 1.8$ \\
\hline Deguelia utilis extract (4 L) & $89.8 \pm 0.6 a b c$ & $92.2 \pm 1.5 \mathrm{a}$ & $97.9 \pm 0.7 a b$ & $88.3 \pm 1.8 \mathrm{a}$ & $94.7 \pm 3.3$ \\
\hline $\begin{array}{l}\text { Derivatives from } \\
\text { crustaceans ( } 3 \mathrm{~L})\end{array}$ & $87.1 \pm 2.6 \mathrm{abc}$ & $88.1 \pm 2.7 \mathrm{a}$ & $95.3 \pm 3.1 \mathrm{ab}$ & $87.8 \pm 1.4 \mathrm{a}$ & $95.4 \pm 1.4$ \\
\hline Na silicate $2 \%(4 \mathrm{~L})$ & $78.8 \pm 3.3 c$ & $91.1 \pm 1.0 \mathrm{a}$ & $94.4 \pm 1.7 \mathrm{ab}$ & $90.1 \pm 2.3 \mathrm{a}$ & $96.7 \pm 1.6$ \\
\hline Copper $7 \%+$ lime $3.3 \%(1.8 \mathrm{~L})$ & $86.8 \pm 2.2 b c$ & $88.9 \pm 2.5 a$ & $87.5 \pm 4.4 \mathrm{ab}$ & $88.4 \pm 2.4 \mathrm{a}$ & $93.4 \pm 1.5$ \\
\hline $\begin{array}{l}\text { Sulfur } 20 \% \text { + quicklime } 10 \% \\
(1.8 \mathrm{~L})\end{array}$ & $83.4 \pm 1.4 b c$ & $88.0 \pm 1.4 \mathrm{a}$ & $89.5 \pm 2.7 \mathrm{ab}$ & $85.8 \pm 3.2 \mathrm{a}$ & $91.2 \pm 3.0$ \\
\hline Chlorpyrifos (384 g) & $3.2 \pm 0.4 d$ & $6.0 \pm 2.7 b$ & $80.1 \pm 12.3 b$ & $2.9 \pm 2.9 b$ & $100.0 \pm 0.0$ \\
\hline Control $\left(\mathrm{H}_{2} \mathrm{O}\right)$ & $89.8 \pm 1.0 \mathrm{ab}$ & $89.7 \pm 2.9 a$ & $96.4 \pm 1.8 \mathrm{ab}$ & $92.6 \pm 1.5 a$ & $96.6 \pm 1.01$ \\
\hline CV (\%) & 6.5 & 7.2 & 10.4 & 6.8 & 8.9 \\
\hline F value & 109.7 & 104.0 & 2.2 & 125.52 & 0.95 \\
\hline $\mathrm{p}$-value & $<0.0001$ & $<0.0001$ & 0.047 & $<0.0001$ & 0.4975 \\
\hline $\mathrm{df}_{\text {model }}$ & 9 & 9 & 9 & 9 & 9 \\
\hline $\mathrm{df}_{\text {residue }}$ & 40 & 40 & 38 & 40 & 36 \\
\hline
\end{tabular}

\#Means \pm standard error followed by the same letter in each assay column are not statistically different by Tukey test $(p>0.05) ;{ }^{8}$ original data followed by statistics perfomed on data transformed into arcsin $\sqrt{X / 100}$ to allow for ANOVA according to Burr and Foster (1972) and Shapiro and Wilk (1965);

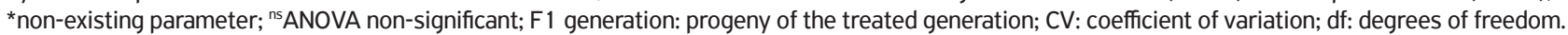


the start of the experiment, in order to evaluate their parasitism capacity. By this means, the sublethal effect (if any) of the products on that insect phase was quantified.

At one day $\left(\mathrm{p}<0.0001 ; \mathrm{F}=104.0 ; \mathrm{df}_{\text {model }}=9 ; \mathrm{df}_{\text {residue }}=40\right)$, after $T$. pretiosum adults emerged from pupae sprayed with the different treatments (Table 2), only the harmful control (chlorpyrifos $384 \mathrm{~g}$ ) differed from the remaining treatments with respect to parasitism (Table 2), being classified as harmful (class 4) while the remaining treatments were classified as harmless (class 1) (Table 3). Similar results were recorded at two days $\left(\mathrm{p}<0.0001 ; \mathrm{F}=125.52 ; \mathrm{df}_{\text {model }}=9\right.$; $\left.\mathrm{df}_{\text {residue }}=40\right)$, after T. pretiosum adults emerged from pupae sprayed with the different treatments (Tables 2 and 3).

\section{DISCUSSION}

The results obtained in this study with the organic products applied on T.pretiosum pupae have shown that these products did not affect the emergence of this species and are compatible with the preservation of those biological control agents. Similar results with the same organic products tested in this research were reported for Telenomus podisi (Hymenoptera; Platygastridae) (Silva; Bueno, 2014). In this context, it is important to emphasize that benefits of agricultural farming go beyond beneficial arthropod preservation. The nutritional quality and the safety of organic food have been well-documented (LAIron, 2010).

Almost all products used in organic agriculture that were evaluated in this research were selective for T. pretiosum (both adult and pupae) and therefore compatible with preservation of the naturally occurring biological control agents. The observed reduction of parasitism observed for the treatment sulfur $20 \%+$ quicklime 10\% 1.8 L indicates a shorten lifespan for adults which had contact with this treatment. Fortunately, T. pretiosum showed greater parasitism in the $24 \mathrm{~h}$ of life (Bueno et al., 2012). This may occur because the reproductive capacity of the parasitoids diminishes with age, besides other biotic and abiotic factors that may influence their behavior (PrATISSOLI et al., 2002). Therefore, even sulfur $20 \%$ + quicklime $10 \% 1.8 \mathrm{~L}$ can be considered safe for T. pretiosum since they did not impact the first $24 \mathrm{~h}$ of parasitism.

The use of bio-protective mixtures such as Bordeaux mixture and lime-sulfur mixture has increased in recent years and has proved to be efficient in controlling several different pests (Medeiros et al., 2003; GonÇalves et al., 2004). However, few studies have evaluated their effect on beneficial arthropods (EғROM et al., 2011). Experiments carried out under field conditions revealed the toxicity of sulfur to some predators (TEODORO et al., 2005). The results obtained here, however, indicated negative effects of the sulfur + lime mixture for T. pretiosum. The mechanisms of action of these products on the insects are not wellknown, but in the case of the lime-sulfur mixture, sulfur, its main component, can inhibit cellular respiration (IRAC, 2009).

Baculovirus anticarsia is highly specific and consequently selective for natural enemies, as demonstrated in this study for the egg parasitoids T. pretiosum. Furthermore, the combined use of different control tactics (baculovirus and egg parasitoids) is not only compatible, but can also be synergic. It was reported that egg parasitoids may act as baculovirus dispersers to other insects that are sensitive to infection by this entomopathogen, thus improving its performance under field conditions (Rosell et al., 2008).

Table 3. Placement of organic agricultural supplies sprayed on the egg parasitoid Trichogramma pretiosum into International Organization for Biological Control survival side effect classes.

\begin{tabular}{|c|c|c|c|c|c|c|c|c|c|c|}
\hline \multirow{3}{*}{$\begin{array}{l}\text { Treatment } \\
\text { (dosage/180 } \mathrm{L} \mathrm{H}_{2} \mathrm{O} \text { ) }\end{array}$} & \multicolumn{4}{|c|}{ Adult bioassay } & \multicolumn{6}{|c|}{ Pupae bioassay } \\
\hline & \multicolumn{2}{|c|}{$\begin{array}{l}1 \text { day after } \\
F_{1} \text { parasitoid } \\
\text { emergence }\end{array}$} & \multicolumn{2}{|c|}{$\begin{array}{l}2 \text { days after } \\
F_{1} \text { parasitoid } \\
\text { emergence }\end{array}$} & \multicolumn{2}{|c|}{ Pupae } & \multicolumn{2}{|c|}{$\begin{array}{c}1 \text { day after } \\
F_{1} \text { parasitoid } \\
\text { emergence }\end{array}$} & \multicolumn{2}{|c|}{$\begin{array}{l}2 \text { days after } \\
F_{1} \text { parasitoid } \\
\text { emergence }\end{array}$} \\
\hline & E\% & Class & E\% & Class & $\mathrm{E} \%$ & Class & $\mathrm{E} \%$ & Class & $\mathrm{E} \%$ & Class \\
\hline Baculovírus anticarsia (140 x $\left.10^{9} \mathrm{cpi}\right)$ & 0 & 1 & 3.1 & 1 & 0 & 1 & 4.48 & 1 & 4.6 & 1 \\
\hline Bacillus thuringiensis (16.8 g) & 0 & 1 & 0.7 & 1 & 0.97 & 1 & 0.48 & 1 & 1.2 & 1 \\
\hline Neem oil (9.6 ppm) & 0 & 1 & 25.9 & 1 & 10.41 & 1 & 0 & 1 & 1.5 & 1 \\
\hline Deguelia utilis extract (4 L) & 0 & 1 & 8.9 & 1 & 0 & 1 & 0 & 1 & 4.6 & 1 \\
\hline Derivatives from crustaceans ( $3 \mathrm{~L}$ ) & 0 & 1 & 2.7 & 1 & 2.99 & 1 & 1.71 & 1 & 5.2 & 1 \\
\hline Na silicate $2 \%(4 \mathrm{~L})$ & 0 & 1 & 30.0 & 1 & 12.24 & 1 & 0 & 1 & 2.7 & 1 \\
\hline Copper $7 \%$ + lime $3.3 \%$ (1.8 L) & 0 & 1 & 11.7 & 1 & 3.28 & 1 & 0.84 & 1 & 4.6 & 1 \\
\hline Sulfur $20 \%$ + quicklime $10 \%(1.8 \mathrm{~L})$ & 7.42 & 1 & 46.5 & 2 & 7.13 & 1 & 1.83 & 1 & 7.4 & 1 \\
\hline Chlorpyrifos (384 g) & 100 & 4 & 100 & 4 & 96.39 & 3 & 93.26 & 3 & 96.6 & 3 \\
\hline
\end{tabular}

$E(\%)=(1-V t / V c) \times 100 . E(\%)$ : percent reduction in parasitism or parasitoid emergence; $V t$ : median parasitism for the treatment tested;

Vc: average parasitism observed for the control treatment (HASSAN, 1992); classes: $1=$ harmless ( $<30 \%) ; 2$ slightly harmful $(30 \% \leq \mathrm{E} \leq 79 \%)$; 3 = moderately harmful ( $80 \% \leq \mathrm{E} \leq 99 \%) ; 4$ = harmful $(\mathrm{E}>99 \%)$. 
Similarly, T. pretiosum was not impacted either by the action of Bacillus thuringiensis (16.8 g), which is another important bioinsecticide used in organic agriculture for the control of lepidopterans. In this experiment, $B$. thuringiensis was selective and thus can be used in organic soybean production with no deleterious effect on this natural enemy. B. thuringiensis $\left(\right.$ Dipel $\left.^{\circledR}\right)$ is one of the most widely used entomopathogens in biological control, for its more rapid action compared to other biological control agents and for encompassing a wide range of targets within the order Lepidoptera (PolanczyK; Alves, 2003). As it is harmless to natural enemies, $B$. thuringiensis has been reported to be compatible with other species of biological-control agents of the genus Trichogramma as, for example, Trichogramma dendrolimi (TAKADA et al., 2001). This compatibility may result from the need for the bacterium to be ingested to have an effect, and therefore the contact via tegument, as analyzed in this experiment, was not able to contaminate the parasitoids.

The effect of B. thuringiensis mixed with the parasitoids' food (honey) on Thichogramma pratissolii adult females was analyzed by other investigators, who concluded that the bacterium can accelerate the parasitism rhythm (PolanczyK; Alves, 2003). This factor still needs further study from the physiological and behavioral viewpoints. This study of ingestion by the parasitoids is also important because, when commercial formulations of $B$. thuringiensis are applied under field conditions, it is possible that honeydew, naturally found in commercial soybean fields, is contaminated by the sprayed product. Therefore, the contaminated honeydew may be ingested by the egg parasitoid adults under field conditions. The possibility of ingestion was not evaluated in the present study, but should be taken into account in further experiments to evaluate the impacts of different natural products.

A broad array of pest-repellent products, including homemade herbal teas, plant extracts, and fermentation products, is also authorized for use in organic agriculture (ZEHNDER et al., 2007). One commonly used botanical pest repellent and insecticide is neem oil [Azadirachta indica A. Juss (Meliaceae)] (Isman, 2006). Neem extracts produce multiple effects on insects, including repellency, reduced feeding, decreased oviposition, interruption of development and ecdysis, reduced fertility and fecundity, behavioral alterations, developmental delay, and mortality (Mordue; Nisbet, 2000). Plant extracts such as neem are reported to be non-selective to natural enemies. After spraying neem oil on eggs of the host A. kuehniella, it was observed a reduction in the parasitism of $T$. pretiosum (Gonçalves-Gervásio; Vendramim, 2004). The product Neemseto ${ }^{\circledR}$ used in the present experiment, however, did not reduce parasitism compared to the control treatment for T. pretiosum in the first $24 \mathrm{~h}$. After that period, Neemseto ${ }^{\circledast}$ was moderately harmful (class 3 ) to T. pretiosum. These differences in results may be due to differences in the concentration of the products used or to methodological differences among the experiments. Many neem-based products are not standardized for the concentration of the active ingredient, and, for this reason, differences in selectivity as well as in the efficiency of commercial formulations may exist and should be evaluated before they are used under field conditions.

The product $\left(\right.$ Arrast $\left.^{\circledR}\right)$ is formulated with an extract of the plant Deguelia utilis (Leguminosae - Papilionoideae) containing rotenone. Rotenone is an insecticidal agent that is approved for use in organic agriculture in the United States, but is not registered in Germany because it is toxic to fish (ZeHNDER et al., 2007). Furthermore, rotenone is reported to cause inhibition of the mitochondrial respiratory chain, reducing oxygen consumption (MASCARO et al., 1998) and the production of ATP (adenosine triphosphate, $\mathrm{C}_{10} \mathrm{H}_{16} \mathrm{~N}_{5} \mathrm{O}_{13} \mathrm{P}_{3}$ ), which is necessary for the metabolism and development of insects. It was observed that different concentrations of Rotenat ${ }^{\oplus}$, formulated from the extract of the plant Ateleia glazioviana (Leguminosae: Papilionoideae), significantly affected the adult of the fruit fly Anastrepha fraterculus (Wiedemann) (Diptera: Tephritidae) (Efrom et al., 2011). Arrast $^{\circledR}$, however, was selective for T. pretiosum as evaluated here, thus showing that it is compatible with the preservation of this important biological control agent.

Besides the side effects of insecticides, it is also important to study the possible side effects of fungicides and herbicides, which are sometimes assumed to be harmless to beneficial arthropods, although this is not always the case (BuENo et al., 2008). Fish fértil Indure ${ }^{\circledast}$ is an organic fertilizer (nitrogen + phosphorus + carbon) derived from natural enzymatic fermentation of marine fish, enriched with chitosan from shells of crustaceans and used for foliar application. This product, which contains a biologically active amino-acid complex, is reputed to act as a natural regulator of the nutritional balance of plants, promoting increased photosynthesis. The chitosan present in Fish fértil Indure ${ }^{\circledast}$ is claimed by the manufacturers to induce the plants' genes to resist to pests and diseases by augmenting their natural defense system. Similarly to the treatment with Fish fértil Indure ${ }^{\circledast}$, the treatment with $2 \%$ sodium silicate was selective for the egg parasitoids evaluated, and thus the use of both products is compatible with the parasitoid.

Differently from the tested organic products, positive control (chlorpyrifos at the dose of $384 \mathrm{~g}$ ) was classified as harmful (class 4) to adults and moderately harmful (class 3 ) to pupae. Chlorpyrifos kills insects primarily by phosphorylation of the acetylcholinesterase enzyme (AChE) at the nerve endings. It causes loss of the available $\mathrm{AChE}$ and over-stimulation of organs by excess of acetylcholine at the nerve endings (CARMo et al., 2010). In the current scientific literature, noxious results of organophosphates on beneficial arthropods have been reported for T. pretiosum (Bueno et al., 2008) and T. cacoeciae (Hassan et al., 1998).

In the historical perspective on integrated pest management (IPM), it was called attention to the earlier IPM proponents who emphasized ecological approaches to establish more 
permanent solutions to pest problems (Kogan, 1998). Thus, the use of organophosphates, whenever possible, could be replaced by other products more compatible with biological control preservation. However, because the organophosphates are among the least expensive insect-control products available to conventional soybean growers, they are often overused (BuENo et al., 2011). Nevertheless, it is important to consider that the price of the pesticide does not reflect the risks and the social costs associated with its use (BENBROoK et al., 1996). If these are taken into account, the benefits of organic farming are more apparent.

\section{CONCLUSION}

Baculovirus anticarsia $140 \times 10^{9} \mathrm{cpi}$; Bacillus thuringiensis $16.8 \mathrm{~g}$; azadirachtin- $A$, azadirachtin- $B$, nimbina and salamina $9.6 \mathrm{ppm}$; rotenoids $4 \mathrm{~L}$; nitrogen $1.3 \%$, phosphorus $3.0 \%$ and total organic carbon $8.0 \% 3 \mathrm{~L}$; sodium silicate $2 \% 4 \mathrm{~L}$; copper $7 \%$ + calcium $3.3 \% 1.8 \mathrm{~L}$; sulfur $20 \%$ + quicklime
$10 \% 1.8 \mathrm{~L}$ are compatible with the use in combination with T. pretiosum in organic pest management. This combination appears to be a viable strategy in the context of sustainable agriculture without impairing the natural biological control promoted by this egg parasitoid, and, therefore, these compatible technologies are feasible for use by organic farmers.

\section{ACKNOWLEDGEMENTS}

The authors are grateful to Conselho Nacional de Desenvolvimento Científico e Tecnológico (CNPq — grants \#501074/2010-4 and 470165/2010-3) and to Coordenação de Aperfeiçoamento de Pessoal de Nível Superior (CAPES — grant\#23038.035744/200889), for financial support, as well as to Adair Vicente Carneiro, for technical assistance. Thanks are also extended to Janet W. Reid, Ph.D., JWR Associates, for the English revision of the manuscript. This paper was approved for publication by the Editorial Board of EMBRAPA Soja as manuscript number 04/2012.

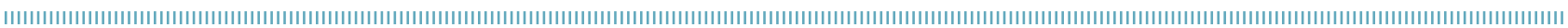

\section{REFERENCES}

BACCI, L.; CRESPO, A.L.B.; GALVAN, T.L.; PEREIRA, E.J.G.; PICANÇO, M.C.; SILVA, G.A.; CHEDIAK, M. Toxicity of insecticides to the sweetpotato whitefly (Hemiptera: Aleyrodidae) and its natural enemies. Pest Managemente Science, v.63, n.7, p.699-706, 2007.

BENBROOK, C.M.; GROTH, E.; HOLLORAN, J.M.; HANSEN, M.K.; MARQUARDT, S. Pest management at the crossroads. Yonkers: Consumers' Union, 1996. 272p.

BUENO, A.F.; BATISTELA, M.J.; BUENO, R.C.O.F.; FRANÇA-NETO, J.B.; NISHIKAWA, A.N.; LIBÉRIO FILHO, A. Effects of integrated pest management, biological control and prophylactic use of insecticides on the management and sustainability of soybean. Crop Protection, v.30, n.7, p.937-945, 2011.

BUENO, A.F.; BUENO, R.C.O.F.; PARRA, J.R.P.; VIEIRA, S.S. Effects of pesticides used in soybean crops to the egg parasitoid Trichogramma pretiosum. Ciência Rural, v.38, n.6, p.1495-1503, 2008.

BUENO, A.F.; FREITAS, S. Effect of the insecticides abamectin and lufenuron on eggs and larvae of Chrysoperla externa under laboratory conditions. BioControl, v.49, n.3, p.277-283, 2004.

BUENO, R.C.O.F.; PARRA, J.R.P.; BUENO, A.F. Biological characteristics and thermal requirements of a Brazilian strain of the parasitoid Trichogramma pretiosum reared on eggs of Pseudoplusia includens and Anticarsia gemmatalis. Biological Control, v.51, n.3, p.355-361, 2009.

BUENO, R.C.O.F.; PARRA, J.R.P.; BUENO, A.F. Trichogramma pretiosum parasitism of Pseudoplusia includens and Anticarsia gemmatalis eggs at different temperatures. Biological Control, v. 60, n.2, p.154-162, 2012.
BURR, I.W.; FOSTER, L.A. A test for equality of variances. Mimeo series n. 282. West Lafayette: University of Purdue, 1972. 26p.

CARMO, E.L.; BUENO, A. F.; BUENO, R.C.O.F. Pesticide selectivity for the insect egg parasitoid Telenomus remus. BioControl, v.55, p.455-464, 2010.

CÔNSOLI, F.L.; ROSSI, M.M.; PARRA, J.R.P. Developmental time and characteristics of the immature stages of Trichogramma galloi and Trichogramma pretiosum Riley (Hymenoptera: Trichogrammatidae). Revista Brasileira de Entomologia, v.43, p.271-275, 1999.

EFROM, C.F.S.; REDAELLI, L.R.; MEIRELLES, R.N.; OURIQUE, C.B. Laboratory evaluation of phytosanitary products used for control of the South American fruit fly, Anastrepha fraterculus, in organic farming. Crop Protection, v.30, n.7, p.1 162-1 167, 2011.

GONÇALVES, P.A.S.; WERNER, H.; DEBARBA, J.F. Avaliação de biofertilizantes, extratos vegetais e diferentes substâncias alternativas no manejo de tripes em cebola em sistema orgânico. Horticultura Brasileira, v.22, n.3, p.659-662, 2004.

GONÇALVES-GERVÁSIO, R.C.R.; VENDRAMIM, J.D. Efeito de extratos de Meliáceas sobre o parasitóide de ovos Trichogramma pretiosum Riley (Hymenoptera: Trichogrammatidae). Neotropical Entomology, v.33, n.5, p.607-612, 2004.

HASSAN, S.A. Guideline for the evaluation of side-effects of plant protection product on Trichogramma cacoeciae. In: HASSAN, S.A. (Ed.), Guidelines for testing the effects of pesticides on beneficial organisms: description of test methods. IOBC/WPRS Bulletin, v.15, p.18-39, 1992. 
HASSAN, S.A.; HAVES, B.O.; DEGRANDE, P.E.; HERAI, K. The side-effects of pesticides on the egg parasitoid Trichogramma cacoeciae Marchal (Hymenoptera: Trichogrammatidae), acute doseresponse and persistence tests. Journal of Applied Entomology, v.122, n.9-10, p.569-573, 1998.

HOFFMANN-CAMPO, C.B.; OLIVEIRA, L.J.; MOSCARDI, F.; GAZZONI, D.L.; CORRÊA-FERREIRA, B.S.; LORINI, I.A.; BORGES, M.; SOSAGÓMEZ, D.R.; CORSO, I.C.; PANIZZI, A.R. Integrated pest management in Brazil. In: MAREDIA, K.M.; DAKOUO, D.; MOTA-SANCHES, D. (Eds.). Integrated pest management in the global arena. Wallingford; Cambridge: CABI Publishing, p.285-299, 2003.

IRAC. INSECTICIDE RESISTANCE ACTION COMMITTEE. Advances in the implementation of pesticide resistance management programs in Brazil, 2009. Disponível em: <http://www.irac-br.org.br/biblio. htm>. Acesso em: 15 fev. 2012.

ISMAN, M.B. Botanical insecticides, deterrents, and repellents in modern agriculture and an increasingly regulated world. Annual Review of Entomology, v.51, p.45-66, 2006.

KLEDAL, P.R.; YU-HUI, Q.; EGELYNG, H.; YUNGUAN, X.; HALBERG, N.; XIANJUN, L. Country report: organic food and farming in China. In: Willer, H.; Yussefi, M. (Eds.). The World of Organic Agriculture and Statistics and Emerging Trends 2007. IFOAM and FiBL, p. 114119, 2007. Disponível em: <http://orgprints.org/10506/>. Acesso em: 10 mar. 2012.

KOGAN, M. Integrated pest management: historical perspectives and contemporary developments. Annual Review of Entomology, v.43, p.243-70, 1998.

LAIRON, D. Nutrional quality and safety of organic food. A review. Agronomy Sustainable Development, v.30, n. 1, p.33-41, 2010.

MASCARO, U.C.P.; RODRIGUES, L.A.; BASTOS, J.K.; SANTOS, E.; COSTA, J.P.C. Valores de $\mathrm{DL}_{50}$ em peixes e no rato tratados com pó de raízes de Derris spp e suas implicações ecotoxicológicas. Pesquisa Veterinária Brasileira, v.18, n.2, p.53-56, 1998.

MCBRIDE, W.D.; GREENE, C. The profitability of organic soybean production. Renewable Agriculture Food System, v.24, n.4, p.276284, 2009.

MEDEIROS, M.B.; WANDERLEY, P.A.; WANDERLEY, M.J.A. Biofertilizantes líquidos: processo trofobiótico para proteção de plantas em cultivos orgânicos. Biotecnologia Ciência $\odot$ Desenvolvimento, v.31, p.38-44, 2003.

MORDUE (LUNTZ), A.J.; NISBET, A.J. Azadirachtin from the neem tree Azadirachta indica: its action against insects. Anais da Sociedade Entomológica do Brasil, v.29, n.4, p.615-632, 2000.

OERKE, E.C. Crop losses to pests. The Journal of Agricultural Science, v.144, n.1, p.31-43, 2006.

OERKE, E.C.; DEHNE, H.W. Safeguarding production: losses in major crops and the role of crop protection. Crop Protection, v.23, n.4, p.275-285, 2004.
PANIZZI, A.R.; CORRÊA-FERREIRA, B.S. Dynamics in the insect fauna adaptation to soybean in the tropics. Trends in Entomology, v.1, p.71-88, 1997.

POLANCZYK, R.; ALVES, S. Bacillus thuringiensis: uma breve revisão. Agrociência, v.7, n.2, p.1-10, 2003.

POLITO, W. Calda Sulfocálcica, bordalesa e viçosa. Os fertiprotetores no contexto da trofobiose. Agroecologia, São Paulo, Part 2, p.20-21, 2000.

PRATISSOLI, D.; FORNAZIER, M.J.; HOLTZ, A.M. GONÇALVES, J.R., CHIORAMITAL, A.B., ZAGO, H.B. Ocorrência de Trichogramma pretiosum em áreas comerciais de tomate, no Espírito Santo, em regiões de diferentes altitudes. Horticultura Brasileira, v.21, n. 1, p.73-76, 2002.

ROSELL, G.; QUERO, C.; COLL, J.; GUERRERO, A. Biorational insecticides in pest management. Journal of Pesticide Science, v.33, p. $103-112,2008$.

SAS INSTITUTE. SAS user's guide: statistics - version 8.2. 6. ed. Cary: SAS Institute, 2001. 201p.

SHAPIRO, S.S.; WILK, M.B. An analysis of variance test for normality. Biometrika, v.52, p.591-611, 1965.

SILVA, D.M.; BUENO, A.F. Toxicity of organic supplies for the egg parasitoid Telenomus podisi. Ciência Rural, v.44, n.1, p. $11-17,2014$.

SONG, F.; SWINTON, S.M. Returns to integrated pest management research and outreach for soybean aphid. Journal of Economic Entomology, v.102, p.2116-2125, 2009.

TAKADA, Y.; KAWAMURA, S.; TANAKA, T. Effects of various insecticides on the development of the egg parasitoid Trichogramma dendrolimi (Hymenoptera: Trichogrammatidae). Journal of Economic Entomology, v.94, n.6, p.1340-1343, 2001.

TEODORO, A.V.; FADINI, M.A.M.; LEMOS, W.P.; GUEDES, R.N.C.; PALLINI, A. Lethal and sub-lethal selectivity of fenbutatin oxide and sulfur to the predator Iphiseiodes zuluagai (Acari: Phytoseiidae) and its prey, Oligonychus ilicis (Acari: Tetranychidae), in Brazilian coffee plantations. Experimental (2) Applied Acarology, v.36, n.1-2, p.61-70, 2005.

VAN LENTEREN, J.C.; BUENO, V.H.P. Augmentative biological control of arthropods in Latin America. Biocontrol, v.48, n.2, p.123-139, 2003.

WILLER, H.; KILCHER, L. The World of Organic Agriculture: statistics and emerging trends 2009. IFOAM FiBL Report. Bonn: IFOAM; Geneva: FiBL, Frick and ITC, 2009. 304p.

ZEHNDER, G.; GURR, G.M.; KÜHNE, S.; WADE, M.R.; WRATTEN, S.D.; WYSS, E. Arthropod pest management in organic crops. Annual Review of Entomology, v.52, p.57-80, 2007. 